\title{
Apropriações melodramáticas: o caso Pedrinho no Jornal Nacional e em Senhora do Destino
}

Walter de Sousa Junior

Doutorando e mestre em Ciências da Comunicação pela ECA-USP.

E-mail: waltersousa@hotmail.com

O noticiário usa elementos do melodrama, apropriando-os da grade de telenovelas, e a telenovela, por sua vez, usa a trama jornalística para conquistar a audiência: um jogo de espelhos em que se evidencia a mistura de gêneros narrativos.

No dia 8 de novembro de 2002, o Jornal Nacional (JN), da Rede Globo, noticiou a alegria de uma família que conseguiu, após dezesseis anos de procura, encontrar o filho roubado de uma maternidade em Brasília. Radiante, exultante, o pai do menino, Jairo Tapajós, queria bater de porta em porta da vizinhança para contar a novidade. A notícia em si, como foi tratada na edição da reportagem, colocava mesmo a alegria da família como personagem principal da história.

Mais precisamente, haviam decorrido dezesseis anos, nove meses e dezoito dias de espera. Um exame de DNA comprovou que uma denúncia apresentada ao SOS Criança era verdadeira. O menino morava em Goiânia e atendia pelo nome de Osvaldo Júnior. Mas para Jairo e Maria Auxiliadora ele seria sempre Pedrinho. No encerramento da reportagem, a mãe obstinada, que passou mais de década e meia acreditando que reencontraria o filho roubado, revelou que "recuperava sua condição de mãe com uma sensação física de saudade", como contou o repórter. "Agora, no telefone, eu senti na hora que falei com ele uma dor como se fosse uma contração, como se fosse um parto", afirmou Auxiliadora. E Jairo completou: "Agora, eu vou abraçar meu filho, com a certeza de que ele vai abraçar o pai dele. Eu tinha certeza que a gente encontrava meu 
filho. Eu tinha muita fé no meu coração. Se eu não tivesse fé no meu coração, eu não teria sobrevivido esses dezesseis anos".

A história, entretanto, não ficou restrita àquela reportagem. Logo se descobriu que o garoto havia sido seqüestrado da maternidade por sua mãe adotiva, Vilma Martins. Com isso, o caso Pedrinho, como ficou conhecido, foi ganhando força com novas revelações, histórias paralelas, investigações policiais e jornalísticas, depoimentos e novos personagens. Daquele 8 de novembro até 22 de maio de 2003, quando Vilma Martins depõe pela primeira vez na Justiça, foram 40 reportagens. Dessas, 23 foram ao ar no mês de novembro de 2002 quase que diariamente.

O caso ganhou novos contornos a partir de fevereiro de 2003, quando se descobriu um outro seqüestro de recém-nascido empreendido pela mesma Vilma Martins, o de Roberta Jamilly, na época da revelação com 24 anos. Naquele mês, foram mostradas 7 reportagens, incluindo os encontros de Roberta com a mãe biológica e entre as duas vítimas de Vilma: Francisca, mãe de Roberta, e Auxiliadora, mãe de Pedrinho.

Os meandros do caso Pedrinho renderam ao JN uma narrativa bem semelhante àquelas que preenchem o restante da grade de programação da Rede Globo, antes e depois do noticiário, ou seja, a da teleficção, empregada na elaboração de telenovelas, seriados e casos especiais. Enfim, um tipo de linguagem diferenciado daquele apontado pelos manuais como a ideal para o jornalismo, ou seja, que prime pela objetividade.

É impossível determinar com muita frieza, muita lógica, o que é uma reportagem. Em resumo, é um documento da realidade, uma narrativa a mais objetiva possível daquela realidade, num determinado momento, que se baseia em dois elementos principais: um agudo senso de observação do repórter e a presença de referenciais universais $[\ldots]^{1}$.

As semelhanças com a narrativa de teleficção, entretanto, não são aparentes nem superficiais. Entre elas estão: a história contada aos pedaços (seriação); o envolvimento do narrador/repórter na própria narrativa; o registro de muitos personagens (no caso Pedrinho, foram 20 coadjuvantes, além dos principais envolvidos das duas famílias) e de diversos núcleos narrativos (Goiânia, Brasília, Taquaral); a importância e o teor dos diálogos (geralmente editados e montados), que criam certo nível de tensão narrativa e possibilitam que a história seja contada não por meio de documentação, mas pela subjetividade dos personagens das reportagens. Ou seja, sabemos o que sentem os pais biológicos de Pedrinho, do embaraço do rapaz, dos sentimentos da irmã Roberta Jamilly, etc., e no exato momento em que estes se manifestam, pois está lá o repórter para registrar tudo.

O leitmotiv ${ }^{2}$ de toda a história é o rapto dos bebês, primeiro de Pedrinho/

1. ABRAMO, Cláudio. A regra do jogo: o jornalismo e a ética do marceneiro. São Paulo: Companhia das Letras, 1988. p. 113.

2. Tema central ou recorrente de uma obra. aldo Júnior, depois de Roberta Jamilly/Aparecida. Essa figura narrativa é arquetípica. Está presente nos mitos arcaicos, nas narrativas populares, no conto maravilhoso e, de forma exemplar, na Bíblia, no primeiro Livro dos Reis, capítulo 3, versículos 16 a 28 do Antigo Testamento, no trecho conhecido como A sentença de Salomão. 
As imagens do noticiário mostram Pedrinho como um adolescente ingênuo, de boa índole, inocente e amoroso. As reportagens apresentam um rapaz dedicado aos estudos, que quase nunca falta às aulas e que vive um difícil rito de passagem: órfão de pai há pouco tempo, descobre que não é filho legítimo de quem chamou de mãe por dezesseis anos, mas de dois desconhecidos que vivem em Brasília. É, portanto, o herói raptado que, segundo o arquétipo do mito, reluta em iniciar sua caminhada pela densa floresta. Esse comportamento está presente na estrutura do conto maravilhoso, como analisou Vladimir Propp: "Assim que o herói vence as provas da floresta ele pode ingressar na 'casa dos homens', ou numa sociedade de iniciados que, na sociedade tribal, é o centro de reunião social"'. Vejamos, pois, como o herói se comporta na estrutura narrativa do JN.

\section{ELEMENTOS MELODRAMÁTICOS}

Numa observação mais aprofundada é possível visualizar na cobertura do JN um gênero que parece conduzir as opções narrativas e estéticas das reportagens: o melodrama. Há elementos que o evidenciam na análise da seqüência narrativa do caso, apontados a seguir.

\section{a) A Providência}

Houve uma faísca inicial que desencadeou a ação da narrativa e essa faísca não foi o rapto, apesar de ser ele o principal arquétipo do caso. O verdadeiro chamado do herói só vai ser conhecido 17 reportagens depois do início da série, quando Gabriela Borges, de 19 anos, uma neta do pai adotivo de Pedrinho, que morreu acreditando ser seu pai biológico, depõe à polícia (a reportagem foi ao ar em 21 de novembro de 2002 e o caso começou a ser reportado treze dias antes). Nesse depoimento a menina revela que ouviu Vilma contando a amigas que há vinte anos não podia ter filhos. Gabriela deduziu que Pedrinho não era seu filho e denunciou o caso ao SOS Criança, o que possibilitou à família Tapajós localizar o rapaz.

Um erro - aparentemente um mero acaso - revela um mundo insuspeito, e o indivíduo entra numa relação com forças que não são plenamente compreendidas. Como Freud demonstrou, os erros não são um mero acaso; são, antes, resultado de desejos e conflitos reprimidos. São ondulações na superfície da vida, produzidas por nascentes inesperadas. E essas nascentes podem ser muito profundas - tão profundas quanto a própria alma ${ }^{4}$.

O melodrama começa a ficar evidente a partir desse toque sutil que desencadeia a transformação na vida do herói: o toque da Providência.

O melodrama é uma narrativa importante na medida em que a história parece responder a forças imperiosas - éticas, providenciais, sagradas. Nesse sentido não é mera obra do autor, mas das leis universais do mundo. Essa dimensão dá segurança aos homens de que algo permanece como em sua origem, apesar das transformações do social ${ }^{5}$.
3. PROPP, Vladimir. As raízes históricas do conto maravilhoso. São Paulo: Martins Fontes, 1997. p. 50.

4. CAMPBELL, Joseph. O herói de mil faces. São Paulo: Cultrix/Pensamento, 1992. p. 60.

5. BROOKS, Peter. L'Immaginazione melodrammatica (A imaginação melodramática). Parma: Pratiche Editrice, 1985. p. 39. 


\section{b) A virtude}

Essa força providencial atua durante toda a peleja entre o vício e a virtude, o bem e o mal, as duas forças antagônicas cuja interação, sempre baseada na perseguição das forças virtuosas pelas negativas, movem a trama melodramática. É, portanto, na figura de Vilma Martins desenhada pelo JN que a série de reportagens se utiliza da gramática do melodrama.

Antes, porém, de esboçar a face da vilania, é preciso definir sua contraparte virtuosa: a família Tapajós. Apesar de Maria Auxiliadora ter sido a maior vítima no caso do seqüestro na maternidade, é Jairo, o pai, quem assume o papel de arauto da Boa-Nova: a volta do filho pródigo. Quando ele surge na tela da TV, falando ao repórter que irá bater de casa em casa para contar que encontrou seu filho, parece ser unicamente dele a angústia da separação. É, portanto, o homem de fé, virtuoso, de bem, e obstinado em sua busca de dezesseis anos pelo filho. Quer bradar aos vizinhos: "Milagres existem!".

No dia seguinte a essa reportagem, Auxiliadora aparece diante de uma pequena capela montada na sala da casa. Agradece a Nossa Senhora Aparecida. Nesse momento, encarna a alma materna por excelência: a própria Virgem Maria, privada de seu filho Jesus. Guardou as roupinhas do enxoval do bebê desaparecido. Escreveu mais de cem cartas ao filho que não viu crescer. Escreveu um livro contando seu drama e sofrimento. Por isso não se constrange ao expor a dor em seu rosto. Reconheceu Vilma desde o início como a enfermeira que estava na maternidade no dia do rapto, mas revelou o fato somente em seu depoimento à polícia. Ocultara o incidente com um único e nobre propósito: poupar Pedrinho.

\section{c) O sofrimento por amor}

A fé não abandona os Tapajós nos momentos mais críticos da relação com Pedrinho. Quando as denúncias contra Vilma e o apelo de Pedrinho parecem desenhar certa ambigüidade nos atos do rapaz, Jairo demonstra preocupação com os efeitos psicológicos das revelações no filho. No programa de Ana Maria Braga, do qual o casal participa no dia em que a Justiça aceita a denúncia contra Vilma, Auxiliadora afirma: "A minha vida foi de muito sofrimento. Eu desejo muito esse filho, ele foi muito amado".

\section{d) A vilania}

Vilma Martins é a figura que monopoliza toda a maldade do caso. A despeito de ter criado Pedrinho por dezesseis anos, período em que o caráter do garoto se formou, e de o rapaz tê-la defendido publicamente, o que revela que ambos mantinham uma relação de confiança e afeição, a mãe adotiva vai se transformando, a cada nova reportagem, num monstro abominável. Ao contrário de Auxiliadora, a mãe biológica, Vilma é sombria. 
Evita falar aos repórteres do JN, usa sempre a figura do seu advogado. Jamais demonstra estar sofrendo, mantém-se dura, o rosto severo agravado pela forma arredondada. De início, sabe-se que é mentirosa: mentiu à polícia (chegou a afirmar que era a mãe biológica de Pedrinho), ao marido morto (disse-lhe que ele era o pai do rapaz), às filhas e ao próprio filho adotivo.

Ela é sempre mostrada fugindo e evitando os microfones. Também fica em silêncio no depoimento à polícia. Mas aos poucos sua face terrível vai sendo desvendada (ou redesenhada). Vilma roubou Pedrinho para obrigar Osvaldo a se casar com ela, pois na época ele vivia com outra mulher. É, portanto, chantagista.

Mas a denúncia mais pesada ainda estaria por vir: a simulação de uma cesariana no hospital de Taquaral, ocasião em que seqüestrou Roberta Jamilly. A história se repete: usa o bebê para chantagear o amante, o industrial Jamal Rassi. Sabe-se pela família dele que Vilma o chantageou por sete anos, chegando a ameaçar as filhas dele.

Revelados os dois casos, comprovados pelos exames de DNA, sua prisão é decretada e Vilma se torna foragida. Chega a se esconder no maleiro de um guarda-roupa para escapar da polícia. Quando, enfim, é capturada e levada à Justiça, sofre crise de hipertensão e sai numa cadeira de rodas da delegacia. A imagem da mãe adotiva cercada pela população exultante mostra já uma quase não-pessoa, ou uma massa física enclausurada em suas mentiras.

\section{e) As vítimas}

Em paralelo, surge a mãe de Roberta Jamilly, dona Francisca, reconhecida prontamente pela moça assim que toma conhecimento do exame de DNA. Apesar de ter sofrido as mesmas agruras de Auxiliadora, surge somente como coadjuvante. É pacata e humilde; afirma desde o início que vai esperar o teste de DNA. Abraça a filha e aponta semelhanças entre as duas: tanto positivas (humildade) como negativas (gênio forte).

Outros 20 personagens participam da trama com depoimentos contundentes ou não, portadores de fatos que corroboram a culpa de Vilma ou desabonam Pedrinho e seus pais biológicos, além de parentes denunciadores, testemunhas resgatadas no tempo pela polícia, juristas e advogados que opinam sobre o caso. Todos coadjuvantes.

A própria Roberta se coloca na posição de coadjuvante. Avisa, de saída (em 23 de novembro de 2002): "Se for preciso, eu faço o DNA. Só que há uma coisa: obrigar, jamais! O caso é Pedrinho. Não usem a minha vida para transformar igual transformou a do Júnior, meu irmão, não”.

\section{f) A peripécia (a reviravolta)}

O fato mais interessante no processo que revelou o novo seqüestro foi o artifício usado pelo delegado para que o exame de DNA, que Roberta se re- 
cusou a fazer, fosse efetivado: foi usada a ponta do cigarro que a moça deixou no cinzeiro da delegacia e que continha as amostras de saliva necessárias para o teste. Um artifício que parece ter saído definitivamente de uma narrativa melodramática e que perde em contundência somente para o comentário de Jairo Tapajós, ao saber da decretação da prisão de Vilma após a confirmação do caso Roberta: "A própria justiça que Deus determinou na vida de todos nós pode tardar, mas falhar nunca”. Enfim, como estabelece a fórmula clássica do melodrama, a virtude triunfa.

\section{g) O resgate (a virtude triunfante)}

James L. Smith assim resume o padrão do melodrama do triunfo:

Há uma fórmula simples para fazer uma peça dar à sua audiência os prazeres fáceis do triunfo. Pegue um homem inocente e uma mulher indefesa e livre-os completamente de qualquer tipo de falha. Apresente-os de forma simpática, de modo que a audiência se identifique com eles e compartilhe de suas esperanças. Coloque-os diante de todos os obstáculos que puder imaginar. Faça-os ser perseguidos por bandidos hostis, ensandecidos, e faça-os acreditar que vivem num mundo em que a cada momento há risco de aniquilação imediata. Dramatize estes elementos de maneira eficaz, controle o suspense com música, aliviando-os com risos e lágrimas. Então, quando tudo parecer perdido, permita que seu herói e sua heroína ganhem. Deixe o vilão derrotado, a loucura ser revertida, o perigo físico superado e a virtude ser recompensada com a alegria infinita ${ }^{6}$.

A edição das reportagens foi conduzindo o caso a um happy end. O gradual afastamento de Pedrinho de Vilma e sua aproximação dos pais biológicos desenham um bom termo para a história. Em 31 de julho de 2003, o JN veicula, enfim, a notícia que faltava: "Depois de mais de dezessete anos de procura e nove meses de carinho e convencimento, Pedrinho, o garoto roubado na maternidade pouco depois de nascer, se mudou. Está vivendo com os pais biológicos".

Pedrinho aparece na tela da TV com o pai. Entra no carro e a reportagem acompanha rapidamente o trajeto dos dois até uma escola em Brasília. Ele acaba de se mudar e vai ao primeiro dia de aula. O repórter avisa que ele deverá prestar vestibular no final do ano para Direito. Jairo beija o filho e afirma, triunfante, à reportagem: "Voltou para casa de onde nunca devia ter saído. Ou melhor, ele nunca devia de lá ser tirado”. É, enfim, o retorno do filho pródigo.

6. SMITH, James L. Melodrama. Londres: Methuen \& Co. Ltd, 1973. p. 15.

7. BROOKS, Peter. Prefácio ao Trattato del Melodrama (Tratado ao melodrama). Parma: Pratiche Editrice, 1985. p. XVI.
A comédia termina tradicionalmente com a vitória da geração mais jovem sobre o ultrapassado, o obstáculo que vem da geração precedente, e com a união de jovens amantes em momento glorioso, que anuncia o nascimento de uma nova sociedade. Nenhuma sociedade está nascendo ao fim do melodrama. No entanto, a velha sociedade, agora purificada, purga-se do elemento do mal, se reforma em torno da personagem de virtude, numa afirmação da moral pública e de valor psicológico ${ }^{7}$. 


\section{O CAMINHO INVERSO: SENHORA DO DESTINO}

A telenovela Celebridade ${ }^{8}$, de Gilberto Braga, entrava na reta final na Rede Globo e as chamadas da sua substituta irrompia nos intervalos pela voz da atriz Eva Wilma, repetindo o slogan: "Toda família tem uma grande história para contar". O novo texto seria de Aguinaldo Silva, que havia iniciado sua ascensão como autor de teleficção ao assumir a difícil tarefa de escrever a quatro mãos com Dias Gomes o retumbante sucesso Roque Santeiro, a única telenovela da história a registrar audiência de 100 pontos no seu último capítulo. Silva começou sua carreira na Globo em 1979 ao escrever, juntamente com Doc Comparato, Antonio Carlos Fontoura e Leopoldo Serran, as aventuras do repórter policial Waldomiro Pena, vivido por Hugo Carvana, no seriado Plantão de Polícia ${ }^{9}$. Personagem inspirado no repórter Octávio Ribeiro, o Pena Branca, falecido em 1986. Ele mesmo havia acabado de sair da redação do jornal $O$ Globo, onde atuara como repórter policial, o que lhe tinha dado uma boa experiência para retratar as desventuras de um repórter romântico na cobertura de casos ocorridos na Baixada Fluminense. No episódio de estréia, Inimigo público, um cidadão da Baixada Fluminense é abordado por policiais quando transportava uma televisão pela rua, e acaba acusado injustamente de roubo.

Escreveu várias minisséries, em seu período inicial na emissora, entre elas a pioneira Lampião e Maria Bonita ${ }^{10}$, além de Bandidos da Falange ${ }^{11}$, Padre Cícero ${ }^{12} \mathrm{e}$ Tenda dos Milagres ${ }^{13}$. A partir de Roque Santeiro ${ }^{14}$, incorporou a fórmula do mestre Dias Gomes: temática regional e realismo fantástico, apropriado da literatura latino-americana, especialmente do brasileiro Jorge Amado (Dona Flor e seus dois maridos) e do colombiano Gabriel Garcia Márquez (Cem anos de solidão).

Essas características se firmaram justamente com uma adaptação de Jorge Amado para o horário das 21 horas, Tieta ${ }^{15}$. O autor alcançou seu auge com A Indomada ${ }^{16}$, êxito em audiência no horário, com 48 pontos, e depois em Porto dos Milagres ${ }^{17}$.

A voz de Eva Wilma, entretanto, não prometia a mesma fórmula para a nova telenovela das 21 horas. As chamadas de Senhora do Destino ${ }^{18}$ levaram a um personagem bem real, Maria do Carmo Ferreira da Silva, uma retirante nordestina que chega ao Rio de Janeiro em 1968 em plena passeata estudantil que protestava contra o recém-baixado Ato Institucional n. 5, que cerceava direitos políticos e endurecia o regime militar, que havia assumido o poder com o Golpe de 1964.

"Cansei de realismo fantástico, chega de mulher voando, quero realidade"19, disse Aguinaldo Silva na época em que a telenovela estreava. A mudança radical no estilo do autor o fez pensar em assinar a telenovela com um pseudônimo. "Queria assinar como Consuelo Meirelles e provar que posso me renovar"

O texto de Silva também prometia ser uma antítese de Celebridade, cuja temática estava nas páginas das revistas de badalação e no mundo da mídia, focando o sucesso a qualquer custo, mesmo que fugaz. "Uma novela sobre e para o brasileiro trabalhador", dizia o material oficial de divulgação da Rede Globo sobre Senhora do Destino.
8. De Gilberto Braga e direção de Denis Carvalho, out. 2003/jun. 2004.

9. De Aguinaldo Silva, Doc Comparato e Antonio Carlos Foutora, com direção de Jardel Mello, Luís Antônio Piá, José Carlos Pieri e Marcos Paulo, maio 1979/out. 1981.

10. De Aguinaldo Silva e direção de Paulo Afonso Grisolli e Luís Antônio Piá, abr./maio 1982.

11. De Aguinaldo Silva e direção de Luís Antônio Piá e Jardel Mello, jan./ fev. 1983.

12. De Aguinaldo Silva e Doc Comparato, com direção de Paulo Afonso Grisolli e José Carlos Pieri, abr./maio 1984.

13. De Aguinaldo Silva, baseada no romance homônimo de Jorge Amado. Direção de Paulo Afonso Grisolli, Maurício Farias e Ignácio Coqueiro, jul./set. 1985.

14. De Aguinaldo Silva e Dias Gomes, com direção de Gonzaga Blota, Marcos Paulo, Jayme Monjardim e Paulo Ubiratan, jun. 1985/fev. 1986.

15. De Aguinaldo Silva, Ana Maria Moretzsohn e Ricardo Linhares. Direção de Reynaldo Boury, Ricardo Waddington e Luís Fernando Carvalho, ago. 1989/mar. 1990.

16. De Aguinaldo Silva e Ricardo Linhares, com direção de Marcos Paulo, fev./out. 1997

17. De Aguinaldo Silva e Ricardo Linhares, baseada nos romances Mar Morto e A Descoberta das Américas pelos Turcos, de Jorge Amado. Direção de Marcos Paulo e Roberto Naar, fev./set. 2001.

18. De Aguinaldo Silva e direção de Wolf Maya, jun. 2004/mar. 2005.

19. Depoimento ao site $<h t t p: / / w w w . t e l e d r a m a t u r g i a$. com.br/senhoradest.htm>.

20.Id. 
Continua o release de divulgação:

Uma história sobre pessoas que vencem na vida através do próprio esforço. Uma trama que traz como tema central Maria do Carmo, mãe de cinco filhos, que venceu na vida através de muita luta, mas que terá como grande batalha a reconquista da sua filha, seqüestrada ainda recém-nascida ${ }^{21}$.

Os elementos buscados pelo autor estavam, de fato, na realidade. Tanto na história do País - o período mais agudo da ditadura militar - quanto na sua história pessoal: Maria do Carmo e Sebastião, irmãos na novela, eram os nomes de sua mãe e tio.

A locação escolhida para as cenas iniciais da teleficção, o local de partida da personagem principal, foi Belém de São Francisco (PE), onde o autor nasceu. Por fim, a trama também era real: a história da mãe que tem a filha recém-nascida roubada por uma falsa enfermeira foi decalcada na série de reportagens do JN conhecida como caso Pedrinho.

As apropriações foram muitas: além de Maria do Carmo e Nazaré (interpretadas por Carolina Dieckmann e Adriana Esteves na primeira fase, que durou quatro capítulos e meio, e Suzana Vieira e Renata Sorrah, na segunda fase, respectivamente), ou Maria Auxiliadora e Vilma Martins, que disputam a filha Lindalva/Isabel (novamente Carolina Dieckmann) - uma versão feminina de Osvaldo/Pedrinho -, há o fato de Nazaré ter roubado a criança para justificar o casamento com o amante.

As atitudes de Nazaré durante toda a trama remetem aos argumentos usados pelo JN para caracterizar a vilania de Vilma Martins: leviandade, chantagem emocional, mentira, dissimulação. "Silva tirou o mote de Senhora do Destino das manchetes dos jornais: o seqüestro do garoto Pedrinho por Vilma Martins Costa. Ela levou o bebê de uma maternidade de Brasília, em 1986, e o criou como se fosse seu filho até ser desmascarada, em 2003"22, reconhece uma reportagem da revista Veja, que se propôs a analisar os motivos do sucesso de audiência da telenovela, já próximo do seu final.

A mesma reportagem aponta que o principal elemento de sucesso da novela é que ela "traz ainda a mais clássica das matérias-primas do folhetim: um embate arquetípico entre o bem e o mal" ${ }^{23}$.

Maria do Carmo, que logo nos capítulos iniciais faz da busca pela filha raptada seu propósito de vida (seu destino), reencontra uma figura importante de sua chegada ao Rio de Janeiro, o jornalista Dirceu, vivido pelo ator José Mayer. Após perder a filha durante a passeata, ela é presa injustamente, confundida com uma ativista, mas salva pelo jornalista, que comprova sua inocência antes de partir para o exílio. Ambos formam o par romântico da trama, embora o coração da protagonista seja ainda disputado pelo bicheiro Giovanni Improtta, papel de José Wilker, a quem, por fim, se entrega no final da trama, com o consentimento de Dirceu. Na verdade o triângulo perfaz o alterego do autor: a nordestina retirante, o jornalista e a síntese da Baixada Fluminense.

Silva muitas vezes reproduz alguns recursos narrativos já prontos do caso veiculado pelo JN. Assim que se reencontra com Maria do Carmo, Dirceu se 
propõe a ajudá-la a reencontrar Lindalva. Para isso descobre uma imagem da falsa enfermeira Nazaré numa foto da passeata publicada num jornal da época e providencia o envelhecimento do rosto da raptora para tentar encontrá-la. O mesmo aconteceu com Vilma Martins, a partir de um retrato falado da época do seqüestro de Pedrinho.

Não foi só a história de Lindalva/Isabel (Pedrinho/Osvaldo) que garantiu a Senhora do Destino a maior audiência na história das telenovelas da Rede Globo, média geral de 49 pontos, com picos em que oitenta de cada cem televisores ligados sintonizam a trama, o que corresponde a 45 milhões de telespectadores. Segundo a revista Veja, "a trama de Aguinaldo Silva condensa tudo o que foi testado e aprovado em novelas de sucesso nos últimos anos" ${ }^{24}$. Discutiu gravidez na adolescência, lesbianismo, corrupção política. "Os temas que mais atraem são aqueles relacionados à família. Como Senhora do Destino é uma novela com algumas ousadias, eu procurei situá-la em torno de uma mesma temática, que é a família”, defende o autor ${ }^{25}$.

Sem sair da estrutura do melodrama, promovendo apropriações da narrativa do telejornal, num processo de mixagem entre gêneros, Silva parece usar a propriedade de autor para elaborar uma metáfora que coroa esse fenômeno de mútuas apropriações que caracteriza a televisão: o casamento de Maria do Carmo com o jornalista Dirceu; da narrativa ficcional com a narrativa jornalística; do caso Pedrinho escrito pelo JN, com a Senhora do Destino, escrita por Silva e pela audiência.

\section{ARQUÉTIPOS CONTRADITOS}

Pouco mais de dois anos depois de ter sua vida revirada pela mídia e pelas verdades ocultadas pela mãe de criação Vilma Martins, Pedrinho, ou Pedro Braule Pinto, com 19 anos, no clamor dos capítulos finais de Senhora do Destino, volta ao noticiário. A revista semanal Veja conseguiu sair na frente ao publicar em 2 de março de 2005 a primeira entrevista de Pedrinho depois de ter-se ausentado por meses das manchetes, que muitas vezes se ocuparam mais de Vilma Martins, que cumpria sua pena pelos seqüestros. $\mathrm{O}$ mais interessante na entrevista é como, em sua sinceridade e ingenuidade, Pedrinho desfaz muito dos arquétipos pintados e retocados pelo Jornal Nacional. Indagado sobre sua relação com Vilma, é enfático ao afirmar: "Ela também é minha mãe e sempre será. [...]. O crime que ela cometeu foi horrível, mas eu a perdoei. Ainda tenho muito carinho por ela. Não havia como não perdoar" ${ }^{26}$. Tais afirmações desfazem a face mais negativa da vilã Vilma, devolvendo-lhe a humanidade que o melodrama não admite ao vilão.

Em contrapartida, ao ouvir a pergunta sobre se sua mãe verdadeira também havia perdoado Vilma, Pedrinho responde de forma dúbia: "Ela age como se tivesse passado uma borracha no passado. Minha mãe costuma dizer que o que importa é nossa vida daqui para a frente" ${ }^{27}$. Assim, risca a face da virtude, não atribuindo diligentemente a característica divina do perdão à mãe bioló-

24. Ibid., p. 66

25. Ibid.

26. VEJA. São Paulo: Ed. Abril, ano 38, edição 1894, 2 mar. 2005.

27. Ibid. 
gica. Por fim, a repórter pede que Pedrinho faça uma comparação entre ele próprio e a personagem de Carolina Dieckmann em Senhora do Destino. "Ela não aceitou a verdade quando a descobriu, chegou a fugir. Eu tentei ser mais frio, manter a cabeça no lugar e enfrentar a situação"28. Enfim, a despeito das apropriações melodramáticas feitas tanto pelo JN quanto pelo autor Aguinaldo Silva, Pedrinho conseguiu tomar para si seu próprio drama e, nisso, construir sua história pessoal.

Resumo: A cobertura do caso Pedrinho pelo Jornal Nacional, da Rede Globo, incorporou elementos melodramáticos, definindo para o espectador o embate entre o bem (os pais biológicos do adolescente) e o mal (a mulher que o raptou ainda bebê da maternidade). Tais elementos foram usados por Aguinaldo Silva na construção da trama da telenovela Senhora do Destino, na mesma emissora, num jogo de espelhos de apropriações e mistura de gêneros narrativos.

Palavras-chave: telejornal, telenovela, audiência.
Abstract: The coverage of the Pedrinho case by Jornal Nacional, of the Globo Television Network, incorporated melodramatic elements, defining to the audience the fight between the good (the teenager's biologic parents) and the evil (the woman who kidnapped him still as a baby in the maternity hospital). Those elements where used by Aguinaldo Silva to build the plot of the Brazilian soap opera Lady of Destiny, of the same Network, in a mirror game of appropriations and mixture of narrative sorts.

Keywords: news program, Brazilian soap opera, audience. 